\title{
The Application of the TADE Integrated Teaching Mode in PLC Courses
}

\author{
Zhang $\mathrm{Na}^{*}$ \\ Shenyang Institute of Engineering \\ Automatic Control Department \\ Shenyang, China \\ zhangna@sie.edu.cn \\ * Corresponding Author \\ Han Xichang \\ Shenyang Institute of Engineering \\ Automatic Control Department \\ Shenyang, China \\ Hanxc@sie.edu.cn
}

\author{
Zhang Yuyan \\ Shenyang Institute of Engineering \\ Automatic Control Department \\ Shenyang, China \\ zhangyy@sie.edu.cn
}

\begin{abstract}
PLC courses require students to have a high practical ability, Students are required to master the basic knowledge of analysis, the design of PLC control system, operation methods to lay a solid foundation for students in the future. However, the main body of the traditional PLC curriculum teaching mode is the teacher, Students are not active in their studies. Such teaching mode severely limits the thinking of the students, Students' learning without enthusiasm and learning achievement is not ideal. In order to solve this problem, in the teaching, the integrated teaching mode of "teaching, asking, doing and evaluating" is introduced to create efficient classroom. In this mode, the student is the main part of the learning, the teacher only responsible for guidance. The model can cultivate students' self-learning ability, independent thinking ability, innovation ability, unity spirit and writing ability. Practice has proved that the model is satisfactory in the teaching effect and the assessment results.
\end{abstract}

Keywords- Teaching;Asking; Doing; Evaluating; Efficient Classroom

\section{INTRODUCTION}

.The integrated teaching mode of TADE ${ }^{[1-2]}$ includes the four necessary link of practice teaching. It aim at cultivating students' learning quality and active learning attitude, to advocate the active participation of students, willing to study, diligently to begin, solidarity and collaboration. It Helps students bound freed from the traditional teaching mode, set up efficient classroom, deepen students' understanding of knowledge, improve innovation ability. The specific meaning of the teaching mode is as follows: $\mathrm{T}$ is Teaching, the teacher first taught students should master the knowledge to students. Using the advanced teaching means to display the complex equipment's working principle and control process of image, shorten the time of theory teaching, leave more time to the students. A is Asking, Asked the questions surrounding the interpretation of the content, inspired by asking students, let students themselves summarize the related content, to give students practice content

\author{
Li Zuowei \\ Shenyang Institute of Engineering \\ Automatic Control Department ZB122 \\ Shenyang, China \\ 935091132@qq.com
}

arrangement, guide students to think for a bold and creative exploration. $\mathrm{D}$ is doing, the teacher explain knowledge to students leave after a certain amount of homework or practice, so that the students in the process of completing the task, skilled application of learned knowledge. $\mathrm{E}$ is Evaluation, including review between students and teachers, by learning from each other between the students, broaden the horizons, achieve the goal of flexible use of knowledge. Model structure is shown in Figure 1. This model emphasizes the cognitive subject study enthusiasm and potential of the play, inspire the students thinking of exploring; Also highlights the teacher to the students' thinking trend, and create a can make the students' initiative and collaborative environment. This way of teaching requirements "teaching" and "learning" in the action of two main body, language, emotion, thinking on interaction, produce resonance, the resonance of implementation, promote each other, to promote learning to teach and to promote the teaching and teaching ${ }^{[3-4]}$. To optimize the teaching process, to achieve the best teaching effect.

\section{INTEGRATION OF TEACHING METHODS ABOUT TADE}

The article narrates the application of the integrated teaching mode in teaching about TADE by the course of "The Principle and Application of Programmable Controller", which is a applied very strong course, have extensive engineering background, has been widely used in industrial control. For such courses, it should be looked for the corresponding industries such as electric power system, mechanical manufacture, and chemical industry to support and build up corresponding knowledge application background and achieve the purpose of their major ${ }^{[5]}$. The course knowledge structure based on the above ideas, and the integration of teaching methods selected the engineering background of power system, around the industry requirement for electrical control technology, With the application of knowledge as the 
main line, with theoretical analysis for bedding, pay attention to knowledge, For example, in the part of the programmable controller in the process of building knowledge, actual engineering background is regarded as the design object of a programmable control system , paying attention to the application of sensors, communications module, touch screen, low-voltage electrical appliances equipment system integration, through the control of the power plant coal conveying process shows that the complex process of writing, and let students understand the sensor technology, computer control technology communication technology, electrical control technology in the practical application of control system. The integration of teaching method about PLAE is mainly to liberate PLC teaching from the traditional teaching methods, closely combined with modern teaching methods, and fade out the boundaries of the theory and practice. under the premise of sufficient for basic knowledge, it used case teaching and provided more opportunities by this method, meanwhile it stimulates students' interest in learning, self-learning ability, analysis and problem solving skills, in order to lets student programming, debugging and modify the program, in the process. Particular way is as follows.

\section{A. Various Forms of Lectures}

The integrated teaching mode change the original mode of teaching, "the teacher speak, students listen to, the teacher do, students look at", and the teacher speak content is divided into several big part of the whole book, each part is divided into a number of knowledge, the teacher according to the knowledge points one by one, students of knowledge points one by one to master, finally to grasp the whole course of all content. Teachers only use a small amount of time on the content of each class, most of the time for the student, lets student operation, understand the content of the teacher speak in practice, the teachers according to different students understanding of targeted for guidance, realize the classroom efficiency.

\section{B. Project Guidance, Task-driven}

Interpretation of knowledge, students independently to complete the task, the teacher gives the specification requirements. This part is mainly with the method of project lead, task driven ${ }^{[6-7]}$, guide students to autonomous learning, and complete the work task. Teachers' role in the learning process is inspired, guided, not given directly conclusion. The method cultivates students' innovation ability and independent analysis and problem solving skills. For example, for the design of the control system and debugging project, teachers does not explain how to design the control system, but the demonstration of the existing control simulation system guide the students, who founds that the problem, sums up experience. Simulation system very clearly tell the students what to do in this project, embodies the guiding role of the project, and, students are fully prepared for learning, but how to start, where to start design, design needs some knowledge of what kind of Students may be a loss. Therefore, teachers need to ask questions to all students, guide students to want to do.

\section{Doing}

After the teacher assignments, students will independently check data, system design, programming, system debugging, finally turned over to the lab report or training practice report.

In this engineering students should make full use of what they have learned, widely browse, independent thinking and combining with the group discussion, thorough research of the different aspects of different levels around the task, even daring to question, and finding the optimal implementation plan, in order to exercise creative thinking ${ }^{[8]}$.

\section{Seminar Teaching}

Discussion teaching mainly has two ways, which is the combination of each task for students that solve their discussion through group discussion in class. Another way for a student's work, it not only arouse the students interest in learning, but also can learn from each other between the students, broaden the horizons, improve the students' ability to analyze and solve problems.

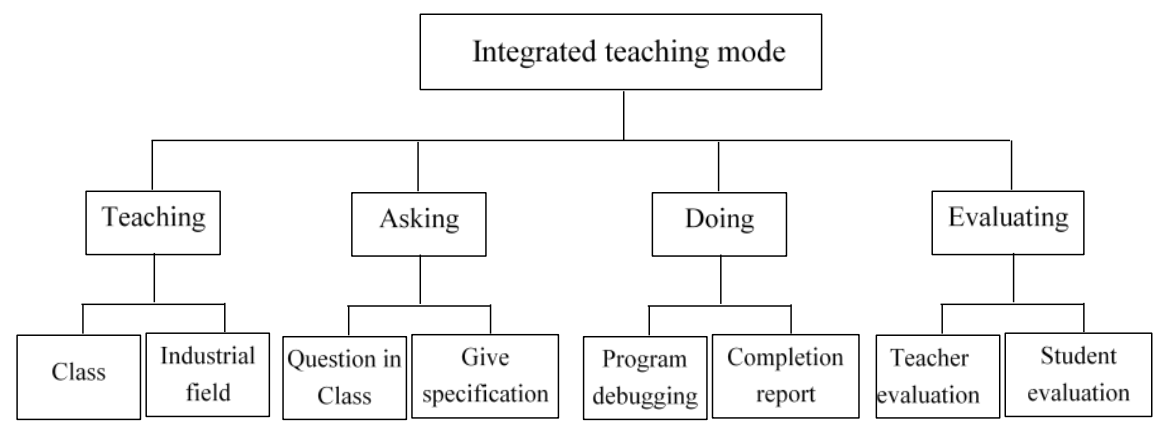

Figure 1. Integrated Teaching Mode Chart 


\section{THE INTEGRATION OF TEACHING MEANS ABOUT TADE}

In order to cooperate with the implementation of the teaching method, the corresponding teaching method should be changed.

\section{A. Multimedia Teaching}

Teachers make a lot of animation teaching course ware and make full use of multimedia technology in resource integration, at the same time it improve the language skills and mastery of students learning psychology, in order to obtain ideal teaching effects. Multimedia teaching make teaching process more image, vivid, the teaching content more refined.

\section{B. Virtual Simulation Teaching}

With the aid of the virtual environment that teachers' own production object for teaching, students can directly witness field work situation, test their programming. In the process of teaching, the virtual environment simulation large-scale production equipment, which realize the programming control of large-scale production equipment. What's more, without any increase in school investment conditions, the virtual environment solve the basic conditions of teaching need, and more than the actual device is beneficial to teaching (Under the environment of the equipment control, people is not afraid of programming errors, don't have to worry about equipment failure ${ }^{[9]}$, and can use fewer points of PLC control points of the equipment).the simulation environment of teaching not only arouse the enthusiasm of the students' learning, but also has the goal and power of the students' learning.

\section{Physical Education}

PLC curriculum plan directly teach in the training room, where teachers direct hands-on teach skills to students through the practical demonstration. In the process of learning, students are enthusiastic about learning and their learning efficiency is very high, because students like to place oneself in the scene of the engineering development environment.

\section{Network Teaching Environment}

The PLC network development course, including teaching plans, teaching outline, electronic lesson plans, teaching theory and practice of multimedia teaching courseware, video, problem sets, test paper and answer network teaching resources, guide the student to use online resources. The purpose is cultivates the habit of using online learning and ability by Accessing to information from the related websites. Teachers open their email address and establish question-answering system to the students.

\section{E. Field Practice}

There are organizing students to view the actual control system, participating in the actual production operation, the scene teaching, and field study. Hiring professional and technical personnel explain the actual control system in the scene that help students understand the theoretical knowledge and technical application of this course, improve the students' practical skills and broadened horizons, experience the real professional environment.

\section{THE INTEGRATION OF TEACHING SUPERIORITY ABOUT TADE}

The integration teaching mode about TADE broke the traditional teaching and evaluation model, and solve the section teaching model in the existing theoretical knowledge and practical skills on the knowledge of coherent, cohesive and other issues; Especially, the modern education means and methods that mobilize the students' subjective initiative, stimulate the students' learning enthusiasm and interest in learning, and cultivate the students' comprehensive ability to analyze problem solving, active classroom atmosphere; Finally, the way both make full use of the teaching space and equipment, and efficient use of limited teaching time, which ensure the students can learn to pleasure, interest to learn.

The practice of lively and interesting effectively take place of the abstract and boring theory knowledge scientifically. It make the students get perceptual knowledge from practice, then the perceptual knowledge rise transform rational knowledge consciously, the consequences of developing the minds of students, training students' practical ability, getting twice the result with half the effort in the whole process of teaching ${ }^{[10]}$.

It can effectively increase the faculty of the theoretical level and practical ability, and can continuously promote teachers to study teaching methods, constantly master new knowledge, new technology in the teaching process, in order to meet the teaching needs, so as to improve teachers' teaching ability and teaching level at the same time, to a certain extent, it can also ease the pressure from shortage of school teachers

\section{CONCLUSIONS}

The results suggest that the integration teaching mode about TADE has achieved good results in the course of "The Curriculum of the Principle and Application of Programmable Controller", the configuration software. Teaching content increased, the PLC course before a semester can only learn basic instructions and some functions, now use the mode after the integration teaching mode can not only learn all the function instructions and the content of the configuration software are also involved. Experimental classes accounted for $10 \%$ of theory class hours before, now experimental classes can reach $50 \%$, the difficulty of the course design, graduation design students have improved. It's very obvious advantage that the teaching mode arouses the enthusiasm of students, stimulate students' creative thinking, improve the beginning ability, etc. This way of teaching can make the two main body of the teaching and learning in the action, language, emotion, thinking interaction. Therefore, it produces resonance, promote each other, to promote learning to teach and to promote the teaching and teaching and to optimize the teaching process, improve the quality of teaching effect. 
TABLE I THE APPLICATION EFFECT OF THIS TEACHING MODE COMPARISON TABLE

\begin{tabular}{|c|c|c|}
\hline Project\% & Before the reform & After the reform \\
\hline $\begin{array}{c}\text { Proportion of } \\
\text { experimental }\end{array}$ & 10 & 50 \\
\hline $\begin{array}{c}\text { Students } \\
\text { independent } \\
\text { operation }\end{array}$ & $50-80$ & 100 \\
\hline $\begin{array}{c}\text { verification } \\
\text { experiment }\end{array}$ & 83 & 13 \\
\hline $\begin{array}{c}\text { Design } \\
\text { experiments }\end{array}$ & 17 & 87 \\
\hline $\begin{array}{c}\text { Experimental } \\
\text { equipment } \\
\text { utilization rate }\end{array}$ & 41 & 67 \\
\hline $\begin{array}{c}\text { Degree of } \\
\text { achievement }\end{array}$ & $50-80$ & 100 \\
\hline
\end{tabular}

\section{ACKNOWLEDGMENT}

This work was supported in part by Liaoning Province Education Science "Twelfth Five-Year Plan" project under Grant No.JG14DB292, JG15DB289 and JG15DB301, Course construction project of quality resources sharing in Liaoning Province.

\section{REFERENCES}

[1] Zhou Ai-zhen, Wang He-ping,Jin Hui et al.Processing technology of Chinese traditional medicine exploration and practice of integrated curriculum teaching $[\mathrm{J}]$. Traditional Chinese Medicine.2011, (04):23-25.
[2] Wei Jie. The application of ATDE teaching mode in the teaching of clinical molecular biology test[J].Lab Med Clin,January 2014, 1(11): 196-202.

[3] Chen Run-feng,Zheng Chao, $\mathrm{Ma} \mathrm{Li}$ et al.Explorations on Comprehensive Experimental Teaching System Based on Research Practice and Innovation.Advances in Analytical Chemistry, 2012, .02 (04): 33-35.

[4] Fogarty L, Strimling P, Laland K N. The evolution of teaching. [J]. Evolution, 2011, 65(10):444-446

[5] Qiao Dong-kai, Huang Chong-lin. The experimental teaching quality of the course of "principle and application of programmable controller"[J]. China Electric Power Education, 2013, 1:143-144.

[6] Liao Ji-wu, Yang Yan-jiang. Study on Motivation of Opening Practical Teaching in Tourism Management [J].Advances in Education, 2012, 02 (03):60-65.

[7] Wang Cheng-yi,Gao Ren.The Study of the Practice Teaching Model Based on the Engineering Concept.Advances in Education, 2011, 013(01):131-135.

[8] SB Wang,HB Tian. Comprehensive Experiment and Crossdiscipline Design and Research of Computer Network [J]. Research \& Exploration in Laboratory, 2012, 9(31):210-213

[9] Su Yi-juan.The Application Research of Virtual Experiment in Computer Experimental Teaching of Colleges [J].Creative Education Studies, 2015, 02 (03):23-27.

[10] Wang Ming-wu .Reform and Practice of Programmable Controller Course [J].Mechanical Management and Development, 2012, (05):160-161. 